\title{
Photoassimilate Production and Distribution in Cherry
}

\author{
J.A. Flore \\ Department of Horticulture, Michigan State University, East Lansing, MI 48824 \\ Desmond R. Layne \\ Department of Horticulture, Clemson University, Clemson, SC 29634
}

\begin{abstract}
The two commercially important fruiting cherries in North America are Prunus cerasus L. (sour) and P. avium L. (sweet). Carbon partitioning between individual organs, reproductive and vegetative, is dependent upon photoassimilate supply from photosynthesis and storage carbohydrate, as well as the ability of the translocation system to deliver these resources to sinks (Layne and Flore, 1995). Sink strength of individual organs varies with time of year, and age of the plant, as the sink demands and seasonal development pattern of the plant changes with time. Herein we will review assimilate supply and storage, seasonal partitioning patterns, and the impact that biotic and abiotic stress has on supply, partitioning, and control.
\end{abstract}

\section{ASSIMILATE SUPPLY}

Leaf. Photosynthetic (A) characteristics of sweet $\left(17.9 \mu \mathrm{mol} \cdot \mathrm{m}^{-2} \cdot \mathrm{s}^{-1}\right.$ $\left.\mathrm{CO}_{2}\right)$ and sour cherry $\left(21.5 \mu \mathrm{mol} \cdot \mathrm{m}^{-2} \cdot \mathrm{s}^{-1} \mathrm{CO}_{2}\right)$ have been described previously (De Jong and Doyle, 1985; Flore and Lakso, 1989; Layne and Flore, 1995). These indicate that cherries rank high among Prunus. There is little genetic variation of A for Prunus species. Flore and Sams (1986) reported differences between sweet and sour cherry and between clones of sour cherry and noted that spur-type selections often had higher rates of A than the standard variety 'Montmorency'. Small similar differences have been reported for spur-type apples (Looney, 1968). Genetic variation for respiration (R) has not been reported for cherry. Respiration could influence the overall carbon balance of the plant, especially if temperatures during the dormant period are high enough to increase metabolic activity. Genetic variation for $\mathrm{R}$ exists and has been investigated in other species, but we know of no studies

Received for publication 6 Oct. 1998. Accepted for publication 17 Nov. 1998. The cost of publishing this paper was defrayed in part by the payment of page charges. Under postal regulations, this paper therefore must be hereby marked advertisement solely to indicate this fact. of this type for cherry, except for the cultivar 'Montmorency' (Kappes, 1985).

When the literature is compared for maximum rates of carboxylation and electron transport for 109 different species, sour cherry had carboxylation and electron transport rates higher than those reported for apple, citrus, or grape (Wullschleger, 1993). Sour cherry had values of $21.5 \mathrm{Vc}$ max for carboxylation and $78 \mathrm{Jmax}$ for electron transport, while woody plants averaged $44 \mathrm{Vc} \max$ and $97 \mathrm{Jmax}$, respectively.

In Prunus, DeJong (1983) found that A, mesophyll conductance $\left(g_{m}\right)$, and leaf conductance $\left(g_{l}\right)$ to water vapor all were related linearly to leaf nitrogen content. Leaf intercellular $\mathrm{CO}_{2}\left(\mathrm{c}_{\mathrm{i}}\right)$ concentrations decreased slightly with increasing $\mathrm{CO}_{2}$ assimilation and leaf $\mathrm{N}$ content, indicating that $\mathrm{CO}_{2}$ assimilation was not being restricted by low intercellular $\mathrm{CO}_{2}$ concentrations or stomatal conductance $\left(\mathrm{g}_{\mathrm{s}}\right)$ from leaves with lower assimilation capacity.

Response to light. Cherry leaf A shows a typical asymptotic response to increasing light, similar to that reported for other $\mathrm{C}_{3}$ plants. Saturation to light occurs at $30 \%$ to $50 \%$ of full sun, light compensation points are $\approx 75-80 \mu \mathrm{mol}$ photosynthetic photon flux $(P P F)$, with reported photochemical efficiencies of 0.025-0.028 $\mu \mathrm{mol} \mathrm{CO}$ fixed/ mol PPF (Layne and Flore, 1992). Whole-tree A shows a different response to increasing light. Compensation points are higher, quantum efficiencies and maximum photosynthetic rates are lower, and saturation does not occur under full-light conditions (Flore and Gucci, unpublished data).

In general, as shade increases, leaves increase in leaf area, are flatter, thinner, and have more chlorophyll per unit weight (Sams, 1980). Leaves preconditioned in this manner have lower light compensation points, similar quantum efficiencies, and lower maximum rates of A. Shoots are longer and thinner, and internodes are shorter, leaf area and the number of lateral shoots increases, and whole-tree dry weight is decreased. The effect can be reversed by eliminating shade, but has the greatest effect on leaves that are in the bud stage, or are not 
yet fully expanded. Levels below $20 \%$ full sunlight have a negative impact on reproduction and cold hardiness (Flore, 1980; Flore and Kesner, 1982; Sams, 1980).

Temperature. The relationship between photosynthesis and temperature for Prunus sp. is parabolic. Cherry has a flat response between 17 and $30{ }^{\circ} \mathrm{C}$ (Sams and Flore, 1983). A true high temperature threshold has not been well established for two reasons. Under field conditions, plants can adapt to higher temperatures (Caldwell et al., 1990; Lang et al., 1978), and unless vapor pressure of water is controlled in assimilation cuvettes, vapor pressure deficits (VPD) between the leaf and air increase with increased temperature. Vapor pressure deficits $>1.5 \mathrm{kPa}$ have been shown to cause stomatal closure and decreased photosynthesis in sour cherry (Beckman et al., 1992).

Leaf age. A increases with leaf expansion, reaches a peak just before full development, then remains steady for two or more weeks before declining (Flore and Lakso, 1989; Sams and Flore, 1982). Roper and Kennedy (1986) found that chlorophyll content, $\mathrm{g}_{\mathrm{s}}$, and quantum efficiency increased in sweet cherry as leaves expanded to a leaf plastochron index of 10, then remained constant until senescence. Seasonal whole-tree profiles have been estimated from single-leaf or branch measurements conducted at predetermined intervals. Sams and Flore (1983) reported two very different patterns of A for 'Montmorency' on the same trees in two different years $(1978,1979)$ depending on crop load and leaf emergence rate. They concluded that there was a strong positive relationship between sink strength (vegetative and reproductive) that influenced leaf $\mathrm{A}$, which could explain the differences in A between the two different years. This observation would indicate that factors other than leaf age greatly influence seasonal patterns of A.

The initiation of gross and net export from sour cherry leaves of different ages, a shoot, or fruit were investigated using carbon balance modeling by Kappes (1985) or by using radioisotopes (Kappes and Flore, 1989). The seventh leaf and the terminal leaf started net export at $\approx 17 \%$ and $51 \%$ expansion, respectively, which coincides with the onset of gross export from the leaf. The whole shoot started exporting at $27 \%$ of expansion. This corresponded to 3,4 , and $17 \mathrm{~d}$ after leaf emergence for the seventh, terminal leaf, and whole shoot, respectively. This study demonstrated that leaf age and position had a major influence on the initiation of export, but once export began it was indicative of greater $\mathrm{CH}_{2} \mathrm{O}$ production than the leaf could utilize.

Fruit. Fruit photosynthesis has been reported for sour cherry (Kappes, 1985; Kappes and Flore, 1986). Sour cherry exhibited a positive net photosynthesis early in development, which was highly dependent upon fruit size, temperature, and light. Sour cherry fruit A contributes a significant portion of the carbon used by the fruit for growth and Rd. For sour cherry, maximum rates of A were reached at $P P F$ of $1000 \mu \mathrm{mol} \cdot \mathrm{m}^{-2} \cdot \mathrm{s}^{-1}$ and maximum temperature of $18^{\circ} \mathrm{C}$. Dark respiration $\mathrm{Q}_{10}$ ranged from 1.5 during fruit growth stage I to 2.0 in stage III. A fruit carbohydrate balance from shortly after full bloom to maturity was developed from models derived from measurements of $\mathrm{CH}_{2} \mathrm{O}$ accumulation and $\mathrm{CO}_{2}$ gas exchange. Daily gross photosynthesis never totally compensated for daily $\mathrm{Rd}$. However, fruit gross photosynthesis contributed $19.4 \%, 29.7 \%$, and $1.5 \%$ of the $\mathrm{CH}_{2} \mathrm{O}$ used during stages I, II, and III for fruit development, respectively. Of the total $\mathrm{CH}_{2} \mathrm{O}$ assimilated, $30.9 \%$ was utilized for dark respiration and $69.1 \%$ was incorporated into fruit dry matter. Similar results have been found for peach (Grossman and DeJong, 1994).

\section{STORAGE CARBOHYDRATE}

Storage carbohydrates are necessary to sustain growth under periods of stress, during dormancy, and are important during initiation of growth in the spring. Nonstructural carbohydrates of sweet cherry fruit change quantitatively and qualitatively during the season (Keller and Loescher, 1989). Nonstructural carbohydrates in sweet cherry consist mainly of starch, sorbitol, sucrose, fructose, glucose, and raffinose. Keller and Loescher (1989) reported that total nonstructural carbohydrates (TNC) were highest at leaf abscission. Shortly before budbreak, TNC decreased in all perennial tissues except the spurs, where they increased. TNC then increased slowly once provided with current year's assimilate until fruit harvest, after which they accumulated at a higher rate. Starch was the most common storage material, sucrose the most predominant soluble carbohydrate during dormancy, and sorbitol the most common soluble carbohydrate during spring budbreak. They speculated that if flower buds developed earlier than vegetative buds, as occurs in the Northwest United States, then flower development must rely upon TNC reserves until enough photosynthetic leaf area was present to provide sufficient photosynthate.

At budbreak, carbohydrate reserves provide the carbon needed for growth until the leaf area of the tree provides enough assimilation to meet sink demand. Johnson and Lakso (1986) found that spurs and shoots on apple did not begin to export carbon to the rest of the plant until 15 to $25 \mathrm{~d}$ after budbreak, and that short shoots began earlier than long shoots. For sour cherry, Kappes (1985) found that net export from a terminal shoot did not occur until $17 \mathrm{~d}$ after leaf emergence when the shoot was about one-quarter $(27 \%)$ of total dry-matter accumulation.

\section{SINK EFFECT}

Sinks for photoassimilates, nutrients, water, and phytohormones include reproductive (flowers and fruits) and vegetative (shoots or roots) tissues. The sink effect is demonstrated in a number of ways: 1) by either a higher net $A$ or a delayed decline in $A ; 2$ ) increased carbon translocation to sinks; or 3) greater dry-matter production per unit leaf area when comparing fruiting vs. nonfruiting trees. The capacity of sink tissues to utilize photoassimilate is referred to as sink demand or sink strength, and it is the product of sink size and activity (Warren Wilson, 1972).

Fruit sink strength changes in cherry during the growing season and is greatest during stage III or final swell of fruit growth. Sams and Flore (1983) found no consistent effect of fruit on A of sour cherry. The sink effect on A in cherry has not been consistent, nor is it demonstrable under all conditions. Possible explanations for this include the requirement for source-limiting conditions, the masking effect of competing sinks, or environmental conditions which favor maximum A. A source limitation occurs when A is limited by the capacity of the reactions that supply photoassimilate (Baysdorfer and Bassham, 1985). However, Flore (1985) found that the leaf : fruit ratio must be $<2$ for the sink effect to occur; Gucci et al. (1991a) noted a significant decline in A and an increase in leaf starch following harvest of sweet cherry, sour cherry (Gucci, 1988), and plum (Gucci et al., 1991b). Roper et al. (1988) did not observe a fruit effect of A when they compared fruiting and nonfruiting sweet cherry trees but leaf : fruit ratio was not reported and, thus, it is difficult to know if the trees were source-limited.

Typically, the sink effect on A is not observed in the morning but rather in the afternoon. Gucci et al. (1991b) noted a greater inhibition of A for defruited plum and sour cherry (Gucci, 1988) in the early afternoon than in the morning. Gucci (1988) speculated that the difference between fruiting and defruited plants occurred because carbohydrates were accumulating in the leaves of defruited plants causing a feedback inhibition of A. Layne and Flore (1993) partially defoliated or continuously illuminated young, nonfruiting sour cherry trees and noted a significant enhancement or reduction respectively of A within $1 \mathrm{~d}$ of treatment. Continuously illuminated plants no longer demonstrated a diurnal change in $\mathrm{A}$ and accumulated significant quantities of leaf starch, whereas partially defoliated plants demonstrated the typical decline in A in the afternoon while leaf starch content actually decreased over time (Layne, 1992, Layne and Flore, 1993). Layne (1992) suggested that the decline in A for partially defoliated plants may have been due to feedback inhibition resulting from a sink-limited condition in the young, potted trees.

The sink effect may be observed under field conditions but it is often not seen in the greenhouse or a protected environment. Light saturation may not be achieved in the greenhouse, thereby reducing $\mathrm{A}$ of source leaves, and hence no feedback inhibition may occur. It has been suggested that the diurnal reduction in A results from increased water loss and a more negative water potential leading to stomatal closure (Weber and Gates, 1990). Neither Gucci et al. (1991b) studying defruited plum in the field, nor Layne and Flore (1993) studying continuously illuminated cherry in the growth chamber could attribute reductions in A to changes in leaf water potential. We suggest that $g_{s}$ decreases because of a reduction in $\mathrm{A}$, not as a result of water stress. 
The sink effect may only be observed under optimal conditions. For example, several days of cloudy weather will lower A such that a sink effect may not be observed (Flore and Lakso, 1989). Even upon return to sunny conditions, it may take $>1$ to $2 \mathrm{~d}$ for the effect to be noted as the trees may be carbohydrate depleted. Since current photoassimilate supports new growth, any environmental stresses that limit growth may cause significant accumulation of carbon, which can feedback inhibit photosynthesis (Luxmoore, 1991).

Leaf damage from insects, diseases, or viruses may reduce leaf area, decrease the source-sink ratio, and reduce the overall photosynthetic potential. Depending on sink demand and environmental conditions, some level of defoliation can be compensated for without detrimental effects on A (Layne and Flore, 1992). When the level of defoliation exceeds that for which compensation can occur, a reduction in A results. When defoliation results in source limiting conditions (e.g., a leaf : fruit ratio of $<2$ for sour cherry) the sink effect will probably be noted (Flore and Lakso, 1989). Using the photosystem II inhibitor, Terbacil, to simulate foliage damage, Hubbard (1995) showed that on healthy mature 'Montmorency' trees A was reduced up to $60 \%$ with full recovery within 7 to $10 \mathrm{~d}$. However, the treatments did not affect fruit yield or fruit quality, regardless of time of application. Root and shoot starch levels were reduced slightly, depending on the timing of the Terbacil application, but there was no effect on return yield.

Drought or flooding stress may directly affect A or affect it indirectly by decreasing the effective leaf area via stomatal closure. Whether droughted or flooded, there have been several reports of reduced stomatal conductance without leaf water deficits. Rootproduced ABA may be transported from stressed roots to leaves where it regulates stomatal behavior (Davies et al., 1990; Jackson and Drew, 1984). For plants affected by soil water deficits, carbohydrates and other reserves may accumulate since sink activity is limited by water. Ranney et al. (1991) compared two cherry cultivars for drought resistance and noted that the greater capacity for osmotic adjustment under water stress in 'Meteor' may have contributed significantly to the greater leaf conductance and A than in 'Colt'. Short-term flooding of sour cherry trees reduced A within $24 \mathrm{~h}$ and both stomatal and nonstomatal components of photosynthesis were affected, although $\mathrm{A} / \mathrm{Ci}$ analysis revealed a large nonstomatal effect (Beckman et al., 1992). In addition to the effect of flooding on ABA-induced stomatal responses (Jackson and Drew, 1984), accumulation of ethanol and other toxic metabolites may also be involved (Kennedy et al., 1992). Depending on the severity and duration of the drought or flooding stress conditions and the source-sink ratio of the tree, the sink effect probably will not be observed until the tree is source limited.

The distance between measured leaves and active sinks should be considered when investigating the sink effect since individual leaves supply carbohydrate to particular sinks. The direction of carbohydrate translocation is coupled to a leaf's orthostichy as demonstrated for sour cherry (Kappes and Flore, 1989). Crews et al. (1975) observed in peach that leaves closer to fruit had higher A than leaves farther away. In general, experiments to examine the sink effect should be undertaken on whole plants, as opposed to individual branches on the tree (Flore and Lakso, 1989). Girdling may be used to isolate individual limbs for study but this may present problems also.

For trees that are not yet reproductive, a sink effect may be observed by photosynthetic enhancement following partial defoliation. This has been demonstrated in fruit crops including cherry (Layne and Flore, 1992, 1993) and apple (Flore and Irwin, 1983; Hall and Ferree, 1976; Proctor et al., 1982) and in annual crops including bean (von Caemmerer and Farquhar, 1984).

Excessive source activity or a lack of sink activity may lead to the accumulation of photoassimilates in the leaf, promoting a feedback inhibition of A (Foyer, 1988). Krapp et al. (1991) suggested that when plants have a source-sink imbalance, in which excessive carbohydrates accumulate in the leaf, photosynthetic proteins decrease and resources are remobilized from leaves and reallocated to sinks.

Depending upon the plant species investigated, the environmental conditions and the source-sink ratio, feedback inhibition may or may not occur and, as yet, the mechanism(s) involved remain to be elucidated definitively.

\section{CARBON ASSIMILATE PARTITIONING}

Annual growth. The first noticeable development occurs in the roots, with a flush of growth prior to any visible foliage development. In general, a bimodal periodicity of root growth is observed for many fruit crops, characterized by a flush of growth in the spring prior to vegetative growth, then another flush of growth after terminal bud set occurs. It is generally thought that the root and shoot are in competition for assimilate resources, and that the aboveground organs have priority over the roots. However, recent studies conducted on cherries indicate that roots develop through the summer (Atkinson and Wilson, 1980; Beckman, 1984), and may have a single period of growth that extends from prior to budbreak until terminal bud set (Atkinson and Wilson, 1980), or until leaf abscission. We have observed (Flore, unpublished, 1995) using minirhizotron technology and 'Montmorency' on $P$. mahaleb, that roots grow throughout the year. We observed a single flush of growth that extended from the onset of shoot growth until midsummer for nonharvested trees and until the first killing frost for harvested trees. Bud development in the spring occurs once sufficient chilling temperatures have accumulated (Westwood, 1993) and endodormancy has been broken (Lang et al. 1978). Initiation of growth (breaking of ecodormancy) is a temperature-driven process that is perceived locally by the bud.

In Michigan, 'Montmorency' leaf emergence and development increase linearly with degree-day accumulations until they are fully developed (Eisensmith et al., 1980). Full leaf emergence occurs on spurs within 20 to $30 \mathrm{~d}$ of budbreak, and may continue up to $60 \mathrm{~d}$ for long shoots. 'Montmorency' sour cherry exhibits only one flush of growth, while sweet cherry may have several flushes depending on the resources available, competition from other sinks, and relief from stress.

Cherry fruit consist of three principal parts: the fleshy mesocarp or flesh, the lignified endocarp (stone or pit), and the embryo and associated seed parts (Tukey and Young, 1939). Cumulative reproductive growth measured as fruit size or fresh weight has been described as a double-sigmoidal pattern in the following stages: the initial phase of exponential growth of the fleshy mesocarp (stage I); the lag phase, a period of reduced mesocarp growth, and development of the embryo and associated seed tissues (stage II); a second exponential phase of fleshy mesocarp development prior to harvest, commonly called "final swell," when the fruit can increase in size by $40 \%$ to $60 \%$ (Connors, 1919; Tukey, 1934). The length of each stage varies with variety and location.

Changes in fruit size are caused by cell division and cell enlargement in varying proportions at different times. Cells of the stony endocarp increase by cell division the pre-bloom through the first days of stage I. For sour cherry, Tukey and Young (1939) reported a 25x increase in cell diameter compared to cell size at bloom. Tukey (1952) observed that the durations of stage I and II were related inversely to night temperature, and that the duration of stage III was correlated positively with night temperature. Comparing three varieties of sour cherry that ripen at different times, Tukey (1934) found that the duration of stage I and III were the same for each variety, and the duration of stage II varied with ripening date.

Recently, DeJong and Goudriaan (1989) have plotted the rate of dry-matter accumulation during fruit development, and their results indicate that there are two distinct phases of active sink activity regardless of peach variety; similar results have been shown for sour cherry (Kappes, 1985). They argue that sink demand is greatest during the initial phase of activity and that there are only two phases of growth.

Flower bud initiation for the next season generally occurs just before (1-2 weeks) terminal bud set on the shoots, until just after cessation of growth (Diaz et al., 1981; Westwood, 1993). There also seems to be a strong inverse relationship between vigor and flower bud initiation (FBI) in fruit crops (Flore, 1994). For sour cherry, FBI may begin during the pit hardening stage of fruit development (Diaz, et al., 1981). During this period, fruit dry-matter accumulation is at its lowest, while vegetative growth is high if the plant is provided with adequate resources (water, light, nutrition). Under conditions that produce high vigor, vegetative bud development has precedence over 
reproductive bud development. Stimulation of growth by water, nitrogen, pruning, or application of GA increases the proportion of vegetative to reproductive buds. Factors that decrease vigor promote FBI (i.e., drought, cropping, application of growth retardants).

Assimilate partitioning is strongly influenced by the sinks that develop. Sink strength for reproductive and vegetative parts of the plant differ spatially and temporally throughout the season (Ho et al., 1989; Patrick, 1989), and throughout the life of the tree. Seasonal drymatter partitioning has been studied for several tree fruit in detail, but only a few studies have focused on cherry. If cherry follows the patterns observed for other stone fruit, then a young nonfruiting tree dry-weight increment for the annual would be expected to have the following pattern: frame $>$ root $=$ leaves $>$ laterals: for young-fruiting trees, leaves $>$ frame $=$ fruit $>$ laterals $>$ roots; in a mature tree, leaves $>$ fruit $>$ frame $>$ laterals $>$ roots. The ratio of dry matter aboveground to that below ground increases with age (Flore and Layne, 1995). Fruit generally have priority when leaves and fruit are in competition for resources. Trees with large crops have less foliage development and smaller increases in trunk girth (Flore, unpublished data). Within a shoot, translocation is limited to the leaf orthostichy. Leaves with angular distances of $144^{\circ}$ use separate translocation paths, while leaves with distances $\leq 72^{\circ}$ shared some of the same paths. Translocation from leaves to fruit likely follows the same orthosticky (Kappes and Flore, 1989).

\section{EXTERNAL FACTORS AFFECTING PARTITIONING}

Water. Drought influences dry-matter partitioning between competing organs, and depends heavily on the season, the climate, and the organs' relative sink strengths. If drought occurs in the spring when vegetative development is high relative to reproductive development, vegetative growth is the first to suffer. In early spring, roots have priority for growth followed by vegetative shoot growth. During stage II of fruit growth when dry-matter accumulation is lowest for fruit, vegetative development is increased by application of water and suppressed by drought, with little effect on fruit development. During final swell of fruit development (stage III), fruit have priority for carbon, there is a noticeable decrease in shoot development, and drought may affect both shoot and fruit growth.

For Prunus, among the vegetative aboveground components, organs that are most to least affected by drought are: leaf growth>shoot extension>leaf emergence>trunk diameter (Olien and Flore, 1990; Flore and Layne, 1995). Although shoot growth is related to water uptake by the root, decreasing soil water availability seems to stimulate root growth. On nonfruiting 2-year-old 'Cavalier' sweet cherry on Giessen 148/1 rootstock grown in a rain exclusion shelter, we observed with a mini-rhizotron that the first response to a mild drought was an increase in root numbers, followed by a decrease in shoot growth, trunk growth, carbon assimilation, and then stomatal conductance (Flore, 1994).

Proebsting and Middleton (1980) and Proebsting et al. (1981) studied the effect of extreme water stress on sweet cherry, peach, and plum trees grown in an arid environment with either very little or no irrigation. They found that growth of fruit and vegetative parts was reduced by severe stress, but the trees survived on $15 \%$ ET. Fruit growth was reduced, and flower buds did not differentiate for the next season.

Light. Light can have a profound effect on vegetative and reproductive growth of trees. Prunus have $\mathrm{C}_{3}$ type metabolism. Yield is related directly to the amount of light intercepted per unit land area for several crops (Flore and Lakso, 1989). Few studies have been conducted on cherry, but in a preliminary report, Flore and Layne (1990) found a linear relationship between light interception and yield in 'Montmorency' sour cherry in a high crop year. In general, as shade increases, vegetative morphology of the tree changes to facilitate light harvesting. We are not aware of shading studies that have determined root growth for cherry; however, shading decreased storage carbohydrate in peach (Gucci and Flore, 1989), and the application of Terbacil decreased root starch content in sour cherry (Hubbard, 1995). Since a greater proportion of the aboveground resources are directed toward leaf production, we would expect that root growth would be reduced under shade, but this hypothesis remains to be tested.

Flower bud formation, fruit growth, and cold hardiness also are affected by light (Flore, 1994; Flore and Kesner, 1982; Kappel, 1980; Sams, 1980). During fruit development, shading decreases fruit size and yield, fruit color and soluble solids, fruit set, and induces early fruit drop. The effect is more pronounced if leaf : fruit ratios are near threshold levels (two leaves per fruit for 'Montmorency'). Full sunlight thresholds for these effects range from $10 \%$ to $50 \%$. Flower bud initiation and development are reduced by shade. Flore and Kesner (1982) estimate that at least $20 \%$ full sun was needed for proper flower bud initiation in sour cherry under Michigan conditions. Internal shading within a tree results in nonuniform fruiting. Often there are more flower buds at the top and near the outer edge of the canopy. Fruit are smaller, and are of poorer quality in the lower and center parts of the tree. Wood and bud hardiness are also decreased by shade. Peach and cherry wood and bud hardiness was reduced by as much as $9{ }^{\circ} \mathrm{C}$ when trees in pots were grown under shade. The decrease in hardiness was associated with a decline in storage carbohydrate (Flore et al., 1983).

Fruit load. Observations and experimental evidence indicate that fruit have priority over other sinks in Prunus (Chalmers and van den Ende, 1974; Richards, 1986). When cropping is heavy, shoot and leaf growth are reduced, shoot, scaffold and trunk diameter growth are reduced, cold hardiness may be decreased (Flore et al., 1983), and vegetative and/or reproductive growth may be less in the next year. Fruit size is dependent upon the leaf : fruit ratio; in sour cherry, less than two leaves per fruit results in smaller fruit (Flore and Lakso, 1989). In the Pacific Northwest where sweet cherry fruit size is very important, it is common practice to adjust leaf : fruit ratios using different pruning techniques.

\section{SUMMARY}

Productivity in cherry is dependent upon assimilate supply and storage, and on the ability to translocate and partition carbon into reproductive structures in an efficient manner that does not compromise vegetative development to sustain growth during the current season, or in the future. In this article we have reviewed carbohydrate supply and partitioning and have indicated the effect of environmental factors on those processes. The interrelationship between the various sinks at different times during the season is especially important if abiotic or biotic stresses occur. It is only with this understanding that a researcher or producer can make intelligent decisions to optimize economic yield over a sustained period.

\section{Literature Cited}

Atkinson, K. and S.A. Wilson. 1980. The growth and distribution of fruit tree roots: Some consequences for nutrient uptake, p. 259. In: D. Atkinson, J.E. Jackson, R.O. Sharples, W.M. Waller (eds.). The mineral nutrition of fruit trees. Butterworths, Borough Green, U.K.

Baysdorfer, C. and J.A. Bassham. 1985. Photoassimilate supply and utilization in alfalfa. A developmental shift from a source to a sink limitation of photosynthesis. Plant Physiol. 77:313-317.

Beckman, T.B. 1984. Seasonal patterns of root growth potential (RGP) of 2 containerized cherry rootstocks, $P$. mahaleb L. and $P$. avium L. cv. Mazzard. MS Thesis, Michigan State Univ., East Lansing.

Beckman, T.G., R.L. Perry, and J.A. Flore. 1992. Short-term flooding affects gas exchange characteristics of containerized sour cherry trees. HortScience 27:1297-1301.

Caldwell, J., J.F. Hancock, and J.A. Flore. 1990. Strawberry leaf photosynthesis acclimation to temperature. HortScience 25:1166. (Abstr.)

Chalmers, O. and B. van den Ende. 1974. Productivity of peach trees: Factors affecting dry-weight distribution during tree growth. Ann. Bot. 39:423-432.

Connors, C.H. 1919. Growth of fruits of peach. New Jersey Agr. Exp. Sta. Annu. Rpt. 80:82-88.

Crews, C.E., S.L. Williams, and H.M. Vines. 1975. Characteristics of photosynthesis in peach leaves. Planta 126:97-104.

Davies, W.J., T.A. Mansfield, and A.M. Hetherington. 1990. Sensing of soil water status and the regulation of plant growth and development. Plant Cell Environ. 13:709-719.

DeJong, T.M. 1983. $\mathrm{CO}_{2}$ assimilation characteristics of five Prunus tree fruit species. J. Amer. Soc. Hort. Sci. 108:303-306.

DeJong, T.M. and J.F. Doyle. 1985. Seasonal relationships between leaf 
nitrogen content (photosynthetic capacity) and leaf canopy light exposure in peach (Prunus persica). Plant Cell Environ. 8:701-706.

DeJong, T.M. and J. Goudriaan. 1989. Modeling peach fruit growth and carbohydrate requirements: reevaluation of the double-sigmoid pattern. J. Amer. Soc. Hort. Sci. 114:800-804.

Diaz, D.H., H.P. Rasmussen, and F.G. Dennis, Jr. 1981. Scanning electron microscope examination of flower bud differentiation in sour cherry. $\mathrm{J}$. Amer. Soc. Hort. Sci. 106:513-515.

Eisensmith, S.P., A.L. Jones, and J.A. Flore. 1980. Predicting leaf emergence of sour cherry (Prunus cerasus L. 'Montmorency') from degree-day accumulations. J. Amer. Soc. Hort. Sci. 104:75-78.

Flore, J.A. 1980. The effect of light on cherry trees. Annu. Rpt. Mich. State Hort. Soc. 110:119-122.

Flore, J.A. 1985. The effect of carbohydrate supply on sour cherry fruit size and maturity. HortScience 20:568.

Flore, J.A. 1994. Stone fruit, p. 233-270. In: B. Schaffer and P.C. Anderson (eds.). Handbook of environmental physiology of fruit crops. Vol. 1: Temperate crops, CRC Press, Boca Raton, Fla.

Flore, J.A., G.S. Howell, and C.E. Sams. 1983. The effect of artificial shading on cold hardiness of peach and sour cherry. HortScience 18:321-322.

Flore, J.A. and C. Irwin. 1983. The influence of defoliation and leaf injury on leaf photosynthetic rate, diffusive resistance, and whole tree dry-matter accumulation in apple. HortScience 18:586.

Flore, J.A. and C. Kesner. 1982. Orchard design for stone fruit based on light interception. Compact Fruit Tree 25:159-165.

Flore, J.A. and A.N. Lakso. 1989. Environmental and physiological regulation of photosynthesis in fruit crops. Hort. Rev. 11:111-157.

Flore, J.A. and D.R. Layne. 1990. The influence of tree shape and spacing on light interception and yield in sour cherry (Prunus cerasus cv. 'Montmorency'). Acta Hort. 285:91-96.

Layne, D.R. and J.A. Flore. 1995. End-product inhibition of photosynthesis in Prunus cerasus L. in responses to whole-plant source-sink manipulation. J. Amer. Soc. Hort. Sci. 120:583-599.

Flore, J.A. and C.E. Sams. 1986. Does photosynthesis limit yield of sour cherry (Prunus cerasus)?, p. 105-110. In: A. Lakso and F. Lenz (eds.). Regulation of photosynthesis in fruit trees. Symp. Proc. Publ., New York State Agr. Sta. Spec. Bul., Geneva, N.Y.

Foyer, C.H. 1988. Feedback inhibition of photosynthesis through source-sink regulation in leaves. Plant Physiol. Biochem. 26:483-492.

Grossman, Y.L. and T.M. DeJong. 1994. Peach '92: A simulation model of reproductive and vegetative growth in peach trees. Tree Physiol. 14:329-345.

Gucci, R. 1988. The effect of fruit removal on leaf photosynthesis, water relations, and carbon partitioning in sour cherry and plum. PhD Diss., Michigan State Univ., East Lansing.

Gucci, R. and J.A. Flore. 1989. La resistenza al freddo nel pesco in relazione a fattori ambientalie pratiche colturali. (The resistance of peach to cold in relation to environmental and cultural conditions). Frutticoltura 51:13-19.

Gucci, R., P.D. Petracek, and J.A. Flore. 1991a. The effect of fruit harvest on photosynthetic rate, starch content, and chloroplast ultrastructure in leaves of Prunus avium L. Adv. Hort. Sci. 5:19-22.

Gucci, R., C. Xiloyannis, and J.A. Flore. 1991b. Diurnal and seasonal changes in leaf net photosynthesis following fruit removal in plum. Physiol. Plant. 83:497-505.

Hall, F.R. and D.C. Ferree. 1976. Effects of insect injury simulation on photosynthesis of apple leaves. J. Econ. Ent. 69:245-248.

Ho, L.C., R.I. Gange, and A.F. Shaw. 1989. Source/sink regulations, p. 306344. In: D.A. Baker and J.A. Milburn (eds.). Transport of photoassimilates. Longman Scientific and Technical, Harlow, Essex, U.K.

Hubbard, M.A.. 1995. The influenced of mites and a photosynthetic inhibitor (Terbacil) on photosynthesis and yield of sour cherry (Prunus cerasus L. "Montmorency'). PhD Diss., Michigan State Univ., East Lansing.

Jackson, M.B. and M.C. Drew. 1984. Effects of flooding on the growth and metabolism of herbaceous plants, p. 47-128. In: T.T. Kozlowski (ed.). Flooding and Plant Growth. Academic, New York.

Johnson, R.S. and A.N. Lakso. 1986. Carbon balance model of a growing apple shoot II. Simulated effects of light and temperature on long and short shoots. J. Amer. Soc. Hort. Sci. 111:164-169.

Kappel. F. 1980. Characterization of the light microclimate in four peach tree canopies and the effect of shading on the growth and leaf photosynthesis of peach trees. MS Thesis, Michigan State Univ., East Lansing.

Kappes, E.M. 1985. Carbohydrate production, balance and translocation in leaves, shoots and fruits of 'Montmorency' sour cherry, Ph.D. dissertation, Michigan State Univ., East Lansing.

Kappes, E.M. and J.A. Flore. 1986. Carbohydrate balance models for 'Montmorency' sour cherry leaves, shoots and fruits during development. Acta Hort. 184:123-127.

Kappes, E.M. and J.A. Flore. 1989. The influence of phyllotaxy and stage of leaf and fruit development on the initiation and direction of gross carbohydrate export from sour cherry (Prunus cerasus L. 'Montmorency') leaves.
J. Amer. Soc. Hort. Sci. 114:642-648.

Keller, J.D. and W.H. Loescher. 1989. Nonstructural carbohydrate partitioning in perennial parts of sweet cherry. J. Amer. Soc. Hort. Sci. 114:969-975.

Kennedy, R.A., M.E. Rumpho, and T.C. Fox. 1992. Anaerobic metabolism in plants. Plant Physiol. 100:1-6.

Krapp, A., W.P. Quick, and M. Stitt. 1991. Ribulose-1,5-bisphosphate carboxylase-oxygenase, other Calvin-cycle enzymes, and chlorophyll decrease when glucose is supplied to mature spinach leaves via the transpiration stream. Planta 186:58-69.

Lang, D.K., E.D. Schulze, M. Evenari, L. Kappen, and U. Buschbam. 1978. The temperature related photosynthetic capacity of plants under desert conditions. I. Seasonal changes in the photosynthetic response to temperature. Oecologia (Berl.) 17:97-110.

Layne, D.R. 1992. Physiological responses of Prunus cerasus to whole-plant source manipulation. PhD Diss., Michigan State Univ., East Lansing.

Layne, D.R. and J.A. Flore. 1992. Photosynthetic compensation to partial leaf area reduction in sour cherry. J. Amer. Soc. Hort. Sci. 117:279-286.

Layne, D.R. and J.A. Flore. 1993. Physiological responses of Prunus cerasus to whole-plant source manipulation. Leaf gas exchange, chlorophyll fluorescence, water relations and carbohydrate concentrations. Physiol. Plant. $88: 45-51$.

Looney, N.E. 1968. Comparison of photosynthetic efficiency of two apple cultivars with their compact mutants. Proc. Amer. Soc. Hort. Sci. 92:34-36.

Luxmoore, R.J. 1991. A source-sink framework for coupling water, carbon, and nutrient dynamics of vegetation. Tree Physiol. 9:267-280.

Olien, M.E. and J.A. Flore. 1990. Effect of a rapid water stress and a slow water stress on the growth of 'Redhaven' peach trees. Fruit Var. J. 44:4-11.

Patrick, J.W. 1989. Assimilate partitioning in relation to crop productivity. HortScience 23:33-40

Proctor, J.T.A., J.M. Bodnar, W.J. Blackburn, and R.L. Watson. 1982. Analysis of the effects of the spotted tentiform leafminer (Phyllonorycterblancardella) on the photosynthetic characteristics of apple leaves. Can. J. Bot. 60:27343740 .

Proebsting, E.L., Jr. and J.E. Middleton. 1980. The behavior of peach and pear trees under extreme drought stress. J. Amer. Hort. Sci. 105:380-385.

Proebsting, E.L., Jr., J.E. Middleton, and M.O. Mahan. 1981. Performance of bearing cherry and prune trees under very low irrigation rates. J. Amer. Soc. Hort. Sci. 16:243-246.

Ranney, T.G., N.L. Bassuk, and T.H. Whitlow. 1991. Osmotic adjustment and solute constituents in leaves and roots of water-stressed cherry (Prunus) trees. J. Amer. Soc. Hort. Sci. 116:684-688.

Richards, D. 1986. Tree growth and productivity-The role of roots. Acta Hort. 175:27-36.

Roper, T.R., J.D. Keller, W.H. Loescher, and C.R. Rom. 1988. Photosynthesis and carbohydrate partitioning in sweet cherry: Fruiting effects. Physiol. Plant. 72:42-47.

Roper, T.R., and R.A. Kennedy. 1986. Photosynthetic characteristics during leaf development in 'Bing' sweet cherry. J. Amer. Soc. Hort. Sci. 111:938-941.

Sams, C. E. 1980. Factors affecting the leaf and shoot morphology and photosynthetic rate of sour cherry (Prunus cerasus L. 'Montmorency'). PhD Diss., Michigan State Univ., East Lansing.

Sams, C.E. and J.A. Flore. 1982. The influence of age, position and environmental variables on net photosynthetic rate of sour cherry leaves. J. Amer. Soc. Hort. Sci. 107:339-344.

Sams, C.E. and J.A. Flore. 1983. Net photosynthetic rate of sour cherry (Prunus cerasus L. 'Montmorency') during the growing season with particular reference to fruiting. Photosyn. Res. 4:307-316.

Tukey, H.B. 1934. Growth of the embryo, seed, and pericarp of the sour cherry (Prunus cerasus) in relation to season of fruit ripening. Proc. Amer. Soc. Hort. Sci. 31:125-144.

Tukey, L.D. 1952. Effect of night temperature on growth of the fruit of sour cherry. Bot. Gaz. 144:155-165.

Tukey, H.B. and J.O. Young. 1939. Histological study of the developing fruit of the sour cherry. Bot. Gaz. 100:723-749.

Warren Wilson, J. 1972. Control of crop processes, p. 7-30. In: A.R. Rees, K.E. Kockshull, D.W. Hand, R.G. Hurd (eds.) Crop processes in controlled environments. Academic, New York.

von Caemmerer, S. and G.D. Farquhar. 1984. Effects of partial defoliation, changes of irradiance during growth, short-term water stress and growth at enhanced $\mathrm{p}\left(\mathrm{CO}_{2}\right)$ on the photosynthetic capacity of leaves of Phaseolus vulgaris L. Planta 160:320-329.

Weber, J.A. and D.M. Gates. 1990. Gas exchange in Quercus rubra (northern red oak) during a drought: analysis of relations among photosynthesis, transpiration, and leaf conductance. Tree Physiol. 7:215-225.

Westwood, M.N. 1993. Temperate zone pomology, Timber Press, Portland, Ore.

Wullschleger, S.D. 1993. Biochemical limitations to carbon assimilation in $\mathrm{C}_{3}$ plants-A retrospective analysis of the A/Ci curves from 109 species. J. Exp. Bot. 44:907-920. 